\title{
Originals
}

\section{Inhibition of angiogenesis on glycated collagen lattices}

\author{
M. Kuzuya, S. Satake, S. Ai, T. Asai, S. Kanda, M. A. Ramos, H. Miura, M. Ueda, A. Iguchi \\ Department of Geriatrics, Nagoya University School of Medicine, Japan
}

Summary Advanced glycation endproduct (AGE) accumulation in extracellular matrix proteins has been demonstrated in diabetic patients with a significant correlation with the severity of diabetic complications. AGE accumulation induces matrix protein cross-link formation, resulting in an increased stiffness of matrix fibres and the reduction of the susceptibility of matrix proteins to proteolytic degradation. We examined whether glycation-induced collagen cross-linking may affect vascular endothelial cell behaviours such as invasion, proliferation and differentiation, using the in vitro angiogenesis model of capillary-like structure formation in three-dimensional matrices of collagen type I. Endothelial cells cultured on collagen gel with angiogenic factors (the combination of fibroblast growth factor-2 and vascular endothelial growth factor) invaded the underlying collagen matrix, and organized capillary-like cord structures in the gel. We found that endothelial cell inva- sion into glycated collagen gel was significantly attenuated without any effect on proteinase activity including cell-associated plasminogen activator and matrix metalloproteinase in the conditioned medium. In addition, subsequent capillary-like cord formation was also inhibited in glycated collagen gel. In contrast, endothelial cell proliferation was enhanced on glycated collagen gel with or without angiogenic factors compared with control collagen gel. These results suggest that the structural alterations of extracellular matrix proteins through the glycation-induced crosslink formation affect the interaction between endothelial cell and extracellular matrix, resulting in the impairment of an adequate neovascularization in diabetic patients. [Diabetologia (1998) 41: 491-499]

Keywords Glycation, endothelial cell, angiogenesis, extracellular matrix, plasminogen activator, matrix metalloproteinase.
Received: 8 August 1997 and in revised form: 25 November 1997

Corresponding author: Dr. M. Kuzuya, Department of Geriatrics, Nagoya University School of Medicine, 65 Tsuruma-cho, Showa-ku, Nagoya 466-8550, Japan

Abbreviations: AGE, Advanced glycation endproduct; DMEM, Dulbecco's modified Eagle's medium; PBS, Dulbecco's phosphate-buffered saline; BSA, bovine serum albumin; SDS-PAGE, sodium dodecyl sulphate-polyacrylamide gel electrophoresis; CS, calf serum; FGF-2, fibroblast growth factor-2; VEGF, vascular endothelial cell growth factor; MMP, matrix metalloproteinase; $\mathrm{NaCNBH}_{3}$, sodium cyanoborohydride; $\mathrm{CNBr}$, cyanogen bromide; EDTA, ethylenediaminetetraacetic acid.
There is growing evidence that the increased nonenzymatic glycation of various tissues, and the accumulation of advanced glycation endproducts (AGEs), are involved in the complications of diabetes mellitus. Nonenzymatic glycation occurs very slowly in longlived proteins within the extracellular matrix, including basement membrane proteins and tissue collagen. In fact, AGE accumulation in the basement membranes and collagen has been demonstrated in diabetic patients with a significant correlation with the severity of diabetic complications [1-3]. Reducing sugars such as glucose react nonenzymatically with free amino groups of proteins to form a reversible Schiff base which is then rearranged to form a more stable Amadori product. This Amadori product is degraded slowly and irreversibly under physiological condi- 
tions, being converted into coloured, fluorescent cross-linked molecules, the so-called AGEs [4, 5].

The extracellular matrix proteins provide anchorage for adjacent cells as well as stimuli for cell differentiation, migration and proliferation through specific binding interactions with distinct types of cell surface matrix protein receptors, such as the integrin family of receptors $[6,7]$. Accumulation of AGEs in matrix proteins may affect attached cell behaviour through the changes in integrin matrix ligand interaction. In fact, we recently demonstrated that the accumulation of AGE on the Matrigel, a model of basement membranes, inhibits endothelial cell differentiation, resulting in inhibition of angiogenesis by impairing the normal interactions of endothelial cell receptors with their specific matrix ligands [8].

Accumulation of AGEs induces abnormality in matrix protein cross-linking, resulting in an increased stiffness of matrix fibres and the reduction of the susceptibility of matrix proteins to proteolytic degradation $[9,10]$. These structural alterations of matrix proteins induced by cross-linking may also affect cell behaviours including cell proliferation and differentiation through mechanisms other than altering integrin matrix ligand interaction $[11,12]$.

Angiogenesis, the formation of new blood vessels, from pre-existing blood vessels, plays a crucial role in many physiological and pathological settings, including embryonic development, wound healing, and collateral blood vessel formation in tissue ischaemia $[13,14]$. Although it is well known that local release of angiogenic factor is essential for the induction of angiogenesis, extracellular matrix proteins also regulate the angiogenesis process $[15,16]$. Recently the in vitro culture models of angiogenesis were created using interstitial extracellular matrix proteins, leading to a common angiogenic phenotype of vascular endothelial cell expressed by the formation of tubular structures resembling capillary blood vessels [17-19]. Experimental arguments suggest that appropriate interactions between endothelial cells and the matrix proteins are required to induce in vitro angiogenesis [17-19]. The in vitro angiogenesis is a suitable model with which to address the mechanisms by which extracellular matrix molecules regulate cell behaviours.

In the present study, we examined whether collagen cross-linking may affect vascular endothelial cell behaviours using an in vitro angiogenesis model, in which vascular endothelial cells can be induced to invade fibrillar collagen within which they form capillary-like structures.

\section{Materials and methods}

Reagents. Rat tail collagen type I was purchased from Collaborative Research, Inc. (Bedford, Mass., USA). Bovine serum albumin (BSA), Glucose 6-phosphate, glycolaldehyde, glycine ethyl ester, and p-aminophenylmercuric acetate were obtained from Sigma Chemical Co. (St. Louis, Mo., USA). D-glucose, sodium cyanoborohydride $\left(\mathrm{NaCNBH}_{3}\right)$, cyanogen bromide $(\mathrm{CNBr})$, EDTA and sodium azide were purchased from Katayama Chemical (Osaka, Japan). Aminoguanidine hydrochloride was obtained from Tokyokasei (Tokyo, Japan). Fibroblast growth factor-2 (FGF-2) and phenylmethyl-sulphonylfluoride were purchased from Boehringer Mannheim $\mathrm{GmbH}$ (Mannheim, Germany) and vascular endothelial cell growth factor (VEGF) was from Genzyme (Cambridge, Mass., USA).

Cell culture. Bovine aortic endothelial cells derived from fetal aorta were isolated as previously described [20] and cultured in Dulbecco's modified Eagle's medium (DMEM; Nissui Pharmaceutical, Tokyo, Japan) containing $10 \%$ calf serum (CS; CSL, Parkville, Australia) and antibiotics. Experiments were performed with endothelial cells at passage between 6 and 10 .

Collagen matrices and glycation. A mixture of collagen type I solution $(1.5 \mathrm{mg} / \mathrm{ml})$ and $10 \%$ of $10 \times$ DMEM was neutralized with $1 \mathrm{~N} \mathrm{NaOH}$ and kept on ice. We added 500, 250, or $20 \mu \mathrm{l}$ of the mixture to 6-well, 24-well, or 96-well plates (Corning, Corning, NY, USA), respectively and allowed to gel for $1 \mathrm{~h}$ at $37^{\circ} \mathrm{C}$. The nonenzymatic glycation of collagen gels was performed by using glycolaldehyde. Glycolaldehyde is frequently used for glycation studies because it undergoes the Amadori rearrangement, forms AGEs, and cross-links proteins [21]. The collagen gels were incubated for $4 \mathrm{~h}$ at $37^{\circ} \mathrm{C}$ with glycolaldehyde $(50 \mathrm{mmol} / \mathrm{l})$ in $0.2 \mathrm{~mol} / \mathrm{l}$ phosphate buffer $(\mathrm{pH} 7.8)$ in the presence or absence of aminoguanidine $(0.25 \mathrm{~mol} / \mathrm{l})$, an inhibitor of both AGE and cross-link formation [22], or $\mathrm{NaC}$ $\mathrm{NBH}_{3}(50 \mathrm{mmol} / \mathrm{l})$, which chemically reduces the Schiff base [21]. In some experiments, collagen gel was incubated with $0.2 \mathrm{~mol} / 1$ glucose 6-phosphate or $0.5 \mathrm{~mol} / 1 \mathrm{D}$-glucose in $0.2 \mathrm{~mol} / \mathrm{l}$ phosphate buffer for 2 weeks or 6 weeks, respectively. The gels were then treated with $1 \mathrm{~mol} / \mathrm{l}$ glycine ethyl ester for $1 \mathrm{~h}$ at $37^{\circ} \mathrm{C}$ to quench the glycation reaction. The gels were rinsed twice with Dulbecco's phosphate-buffered saline (PBS) and further incubated with PBS overnight to completely remove any glycolaldehyde and glycine ethyl ester from the gel. As control, collagen gel was incubated with $0.2 \mathrm{~mol} / \mathrm{l}$ phosphate buffer ( $\mathrm{pH}$ 7.8) without glycolaldehyde, treated with glycine ethyl ester, and rinsed with PBS as described above. For thin coating of collagen, the 96-well plates were treated with collagen type I solution at a concentration of $2.5 \mu \mathrm{g} / 50 \mu \mathrm{l} 0.02$ $\mathrm{N}$ acetic acid overnight. The microwells were then glycated as described above. Glycation of BSA was performed by incubating BSA $(100 \mathrm{mg} / \mathrm{ml})$ in $0.2 \mathrm{~mol} / \mathrm{l}$ phosphate buffer $(\mathrm{pH} 7.8)$ containing either $0.5 \mathrm{~mol} / \mathrm{l} \mathrm{D}$-glucose, $1.5 \mathrm{mmol} / \mathrm{l}$ phenylmethyl-sulphonylfluoride, $0.5 \mathrm{mmol} / 1$ EDTA, and $1 \mathrm{mmol} / 1$ sodium azide at $37^{\circ} \mathrm{C}$ for 6 weeks (AGE-BSA), or $50 \mathrm{mmol} / \mathrm{l}$ glycolaldehyde at $37^{\circ} \mathrm{C}$ overnight (glyco-BSA). Following the incubations, the samples were dialysed extensively against phosphate buffer (0.01 mol/l, pH 7.4).

Analysis of collagen cross-linking, and solubility. Glycated collagen gels treated in the presence or absence of aminoguanidine or $\mathrm{NaCNBH}_{3}$ as described above, were transferred into Eppendorf tubes, washed twice with PBS and centrifuged at $10000 \mathrm{rev} / \mathrm{min}$ for $5 \mathrm{~min}$. The pellets were suspended in $500 \mu \mathrm{l}$ of $70 \%$ formic acid and $5 \mu \mathrm{l}$ of $\mathrm{CNBr}$ solution $(2 \mathrm{~g} / \mathrm{ml}$ in acetonitrile). Following overnight incubation at room temperature, samples were extensively dialysed against distilled water. These CNBr peptides were analysed by sodium dodecyl sulphate-polyacrylamide gel electrophoresis (SDS-PAGE). This was carried out under reducing conditions by using a $4 \%$ stacking and a $5-15 \%$ resolving gel, followed by Coomassie 
blue staining. To determine the collagen solubility, the collagen gels were transferred into Eppendorf tubes, washed twice with PBS and centrifuged at $10000 \mathrm{rev} / \mathrm{min}$ for $5 \mathrm{~min}$. The pellets were incubated in $50 \mathrm{mmol} / \mathrm{l}$ Tris- $\mathrm{HCl}(\mathrm{pH} 7.4)$ containing $0.1 \mathrm{~mol} / 1 \mathrm{NaCl}, 15 \mathrm{mmol} / \mathrm{C} \mathrm{CaCl}_{2}$, and collagenase (200 U/ml, Sigma) for $24 \mathrm{~h}$ at $37^{\circ} \mathrm{C}$. After this treatment, the soluble collagen was separated from insoluble collagen fibrils by centrifugation $(12000 \mathrm{rev} / \mathrm{min}, 10 \mathrm{~min})$. The insoluble collagen fibrils were then hydrolysed in $5 \mathrm{~mol} / \mathrm{l} \mathrm{HCl}$ for $3 \mathrm{~h}$ at $60^{\circ} \mathrm{C}$. The solubilization percentage of collagen was determined by measuring the protein content.

In vitro angiogenic assay. Endothelial cells suspended in $10 \%$ $\mathrm{CS}$ plus DMEM were plated $\left(3.0 \times 10^{5}\right.$ cells $\left./ 1 \mathrm{ml}\right)$ on the pretreated collagen gels in 24-well plates as described above. Following cell attachment, angiogenic factors, the combination of FGF-2 $(10 \mathrm{ng} / \mathrm{ml})$ and VEGF $(30 \mathrm{ng} / \mathrm{ml})$, two well-characterized direct-acting angiogenic factors [11, 13, 23], were added to the medium. These two angiogenic factors induce in vitro angiogenesis in a synergistic manner [24, 25]. The medium was replaced every 3 days. On day 2, the number of endothelial cell that invaded the underlying collagen gels was counted under phase contrast microscopy (magnification: $200 \times$ ) from four randomly selected fields of duplicate wells for each experimental condition.

Endothelial cell migration assay. The endothelial cell migration assay was performed using modified Boyden chambers (6.5 mm diameter, $10 \mu \mathrm{m}$ thickness, $5 \mu \mathrm{m}$ pores, Transwell; Costar Corp., Cambridge, Mass., USA) containing polycarbonate membranes. The membranes of the upper chambers were coated with $50 \mu \mathrm{g} / \mathrm{ml}$ collagen type I overnight at $4{ }^{\circ} \mathrm{C}$, followed by treatment with $50 \mathrm{mmol} / \mathrm{l}$ glycolaldehyde in $0.2 \mathrm{~mol} / 1$ phosphate buffer or with phosphate buffer alone for $4 \mathrm{~h}$ at $37^{\circ} \mathrm{C}$. The membranes were then treated with $1 \mathrm{~mol} / \mathrm{l}$ glycine ethyl ester for $1 \mathrm{~h}$ and rinsed with PBS twice. The upper chambers were placed into the lower chambers containing $600 \mu \mathrm{l}$ DMEM plus $0.3 \% \mathrm{BSA}$ in the presence or absence of $10 \mathrm{ng} / \mathrm{ml} \mathrm{FGF-2}$ and $30 \mathrm{ng} / \mathrm{ml}$ VEGF. Endothelial cell suspension $\left(5 \times 10^{5}\right.$ cells/ $100 \mu \mathrm{l}$ ) in DMEM plus $0.3 \%$ BSA was then added to the top of each migration chamber and allowed to migrate to the underside of the top chamber for $12 \mathrm{~h}$ at $37^{\circ} \mathrm{C}$. Non-migratory cells on the upper membrane surface were removed with cotton swab, and the migratory cells attached to the bottom surface of the membrane were stained. The migration was quantified by counting the number of migratory cells in eight randomly chosen high power fields $(\times 400)$ of duplicated chambers.

Endothelial cell-associated plasminogen activator activity. Endothelial cell-associated plasminogen activator activity was determined using the chromogenic substrate S-2251 (Kabi Vitrium, Stockholm, Sweden), a sensitive and specific substrate for plasmin as described previously [20]. Endothelial cells were cultured with $10 \%$ CS plus DMEM on the pretreated collagen gels in 96-well plate as described above. At confluency the cells were treated with $10 \%$ CS plus DMEM in the presence or absence of angiogenic factors (10 ng/ml FGF-2 plus $30 \mathrm{ng} / \mathrm{ml}$ VEGF) for $24 \mathrm{~h}$ at $37^{\circ} \mathrm{C}$, the wells were rinsed twice with PBS and incubated with $100 \mu \mathrm{l}$ of plasminogen $(0.5 \mathrm{U} / \mathrm{ml}), \mathrm{S}-2251$ $(275 \mu \mathrm{g} / \mathrm{ml}), 10 \mathrm{mmol} / 1$ EDTA, and $0.1 \%$ Triton X-100 in Tris$\mathrm{HCl}(\mathrm{pH} 7.4)$. The plate was incubated at $37^{\circ} \mathrm{C}$, and the optical density at $405 \mathrm{~nm}$ was measured within $2 \mathrm{~h}$. No plasminogen activator activity was observed in the absence of plasminogen in the reaction mixture.

Assay for matrix metalloproteinase activity. Matrix metalloproteinase (MMP) activity was measured in endothelial cell-con- ditioned medium using an assay based on the cleavage of a synthetic, fluorogenic peptide substrate, 7-Methoxycoumarin-4Acetyl-Pro-Leu-Gly-Leu-(3-[2, 4-Dinitrophenyl]-L-2, 3-Diaminopropionyl)-Ala-Arg- $\mathrm{NH}_{2}$ (American Peptide Company, Sunnyvale, Calif., USA) [26]. This substrate is sensitive for collagenase, stromelysin and gelatinase and suitable for the assessment of total MMP activity. One $\mathrm{ml}$ of endothelial cell suspension $\left(1.5 \times 10^{6}\right.$ cells $/ \mathrm{ml}$ in DMEM $+0.3 \%$ BSA $)$ was added onto control or glycated collagen gels in a 6-well plate. Following $2 \mathrm{~h}$ incubation, angiogenic factors (10 ng/ml FGF-2 plus 30 $\mathrm{ng} / \mathrm{ml}$ VEGF) were added and further incubated for $32 \mathrm{~h}$ at $37^{\circ} \mathrm{C}$. Supernatants were collected, and incubated with $2 \mathrm{mmol} / \mathrm{l} \mathrm{p}$-aminophenylmercuric acetate for $20 \mathrm{~h}$ at $37^{\circ} \mathrm{C}$ to activate pro-MMPs. These samples were treated with the peptide substrate at a final concentration of $12 \mu \mathrm{mol} / 1$ for $2 \mathrm{~h}$ at $37^{\circ} \mathrm{C}$. The reactions were stopped by addition of an equal volume of $3 \%$ acetic acid. The fluorescence intensity was measured with a Hitachi F-3010 spectrofluorometer (Hitachi Ltd., Tokyo, Japan) at an excitation wavelength of $328 \mathrm{~nm}$ and an emission wavelength of $400 \mathrm{~nm}$. MMP activity was determined by subtraction of the fluorescence intensity of the culture medium blank from the sample values.

Cell proliferation assays. Endothelial cells were plated on pretreated collagen gel in a 96-well plate or collagen-coated 96well plate at $5 \times 10^{3}$ cells in $100 \mu \mathrm{l}$ of DMEM containing $10 \%$ CS. After $1-2 \mathrm{~h}$ of incubation to allow cell attachment, medium was replaced with $10 \%$ CS plus DMEM in the presence or absence of angiogenic factors (10 ng/ml FGF-2 plus $30 \mathrm{ng} /$ $\mathrm{ml}$ VEGF). Following 3 days' incubation at $37^{\circ} \mathrm{C}$, cell number was assessed by a colourimetric methods, the Cell Titer96 AQ Assay kit (Promega, Madison, Wis., USA) as described previously [20].

Statistical analysis. Data are expressed as mean \pm SEM. All analyses were performed with StatView software (Abacus Concepts, Inc. Berkeley, CA, USA) using Student's $t$-test for unpaired data. A level of $p$ less than 0.05 was accepted as statistically significant.

\section{Results}

Effect of glycation on fibrillar collagen properties. The effect of nonenzymatic glycation on the crosslinking of collagen was examined by comparing the size of $\mathrm{CNBr}$ peptides by SDS-PAGE analysis. Figure 1 shows that glycolaldehyde treatment of collagen gel induced the formation of high molecular weight $\mathrm{CNBr}$ fragments which did not penetrate the stacking gel. This finding supports the fact that collagen molecules were cross-linked by glycolaldehyde. Treatment with glucose 6-phosphate $(0.2 \mathrm{~mol} / \mathrm{l})$ for 2 weeks or with D-glucose $(0.5 \mathrm{~mol} / \mathrm{l})$ for 6 weeks had the same effect on collagen cross-linking (data not shown). The addition of either aminoguanidine or $\mathrm{NaCNBH}_{3}$ was sufficient to inhibit these cross-linking reactions (Fig.1).

To further confirm collagen cross-linking, the solubility in collagenase was examined. As shown in Figure 2 , the percentage of fibrillar collagen solubilized in collagenase was significantly reduced in glycated sample. Aminoguanidine or $\mathrm{NaCNBH}_{3}$ prevented 


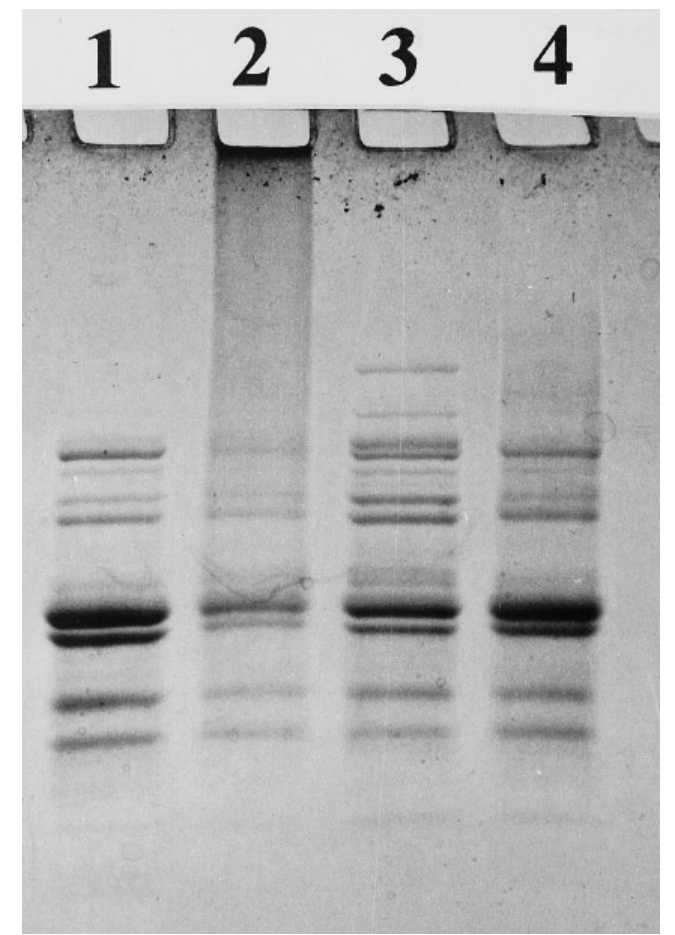

Fig. 1. Cross-linking of collagen fibrils. Collagen gels were incubated with glycolaldehyde (lane 2) in the presence or absence of aminoguanidine (lane 3) or $\mathrm{NaCNBH}_{3}$ (lane 4). $\mathrm{CNBr}$ peptides were prepared and analysed by SDS-PAGE as described under Materials and methods. Lane 1 contains $\mathrm{CNBr}$ peptides from control collagen gels

the limited digestion by collagenase. We also examined the pepsin digestion and the same results were observed (data not shown).

Endothelial cell behaviour on glycated collagen gels. When endothelial cells were plated on collagen gel, they attached to the matrix within $1 \mathrm{~h}$ and formed a polygonal shape in $3 \mathrm{~h}$. In the presence of angiogenic factors (the combination of $10 \mathrm{ng} / \mathrm{ml} \mathrm{FGF}-2$ and 30 $\mathrm{ng} / \mathrm{ml}$ VEGF), a number of spindle shaped endothelial cells invaded the underlying collagen matrix in 2 days (Fig. 3A, B). In 7 days capillary-like cord structures consisting of invading cells were seen just below the endothelial cells monolayer on the surface of the collagen gel (Fig. 4B). In the absence of angiogenic factors, only a few cells invaded and no cord formation was observed in the collagen gel (Fig.4A).

On the glycated collagen gel, endothelial cell attachment and spreading were similar to that on control collagen. No morphological differences were found between control and glycated collagen gel. Following 2 days' incubation in the presence of angiogenic factors, a decreased number of invading cells was observed in glycated collagen compared with that in control collagen gel (Table 1). In addition, the morphology of invading cells exhibited the characteristic elongated phenotype sprouting cytoplasmic

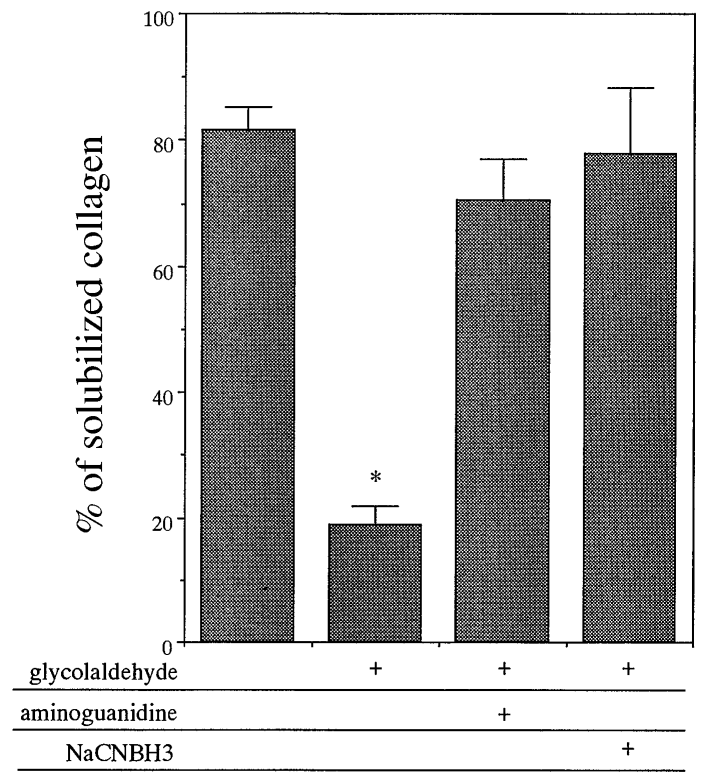

Fig. 2. The percentage of soluble collagens obtained by digestion with collagenase. Data are expressed as means \pm SEM $(n=3) . * p<0.01$ vs control

extensions and ruffles (Fig. 3C, D). At day 7 only a few immature cord structures were seen in the glycated collagen gel and most of the invading endothelial cells had the elongated cell shape with cytoplasmic extensions (Fig. 4C, D).

We examined whether AGE molecules on collagen affected endothelial cell attachment and spreading on glycated collagen. When endothelial cells were suspended with $0.3 \%$ AGE-BSA or $0.3 \%$ glyco-BSA for $30 \mathrm{~min}$ and then plated on glycated collagen gel, cell attachment and morphology similar to without soluble AGE were observed. In addition, in the presence of AGE-BSA or glyco-BSA, a similar angiogenic response of endothelial cells was observed with angiogenic factors (data not shown).

When endothelial cells were grown on collagen gels pretreated with glycolaldehyde in the presence of aminoguanidine or $\mathrm{NaCNBH}_{3}$, endothelial cells invaded underlying collagen and formed capillary-like cord structures in the presence of angiogenic factors to the same extent as in the control collagen gel (Fig. 4E, F). Table 1 shows the summary of the invading cell number in various collagen gels at day 2 .

Effect of glycation on endothelial cell migration. To determine whether glycated collagen molecules affect endothelial cell migration and chemotaxis, migration assay was performed using modified Boyden chambers containing membranes coated with glycated collagen type I. As shown in Table 2, angiogenic factors stimulated endothelial cell migration. No effect of collagen glycation was observed on angiogenic factors-directed endothelial cell migration. 


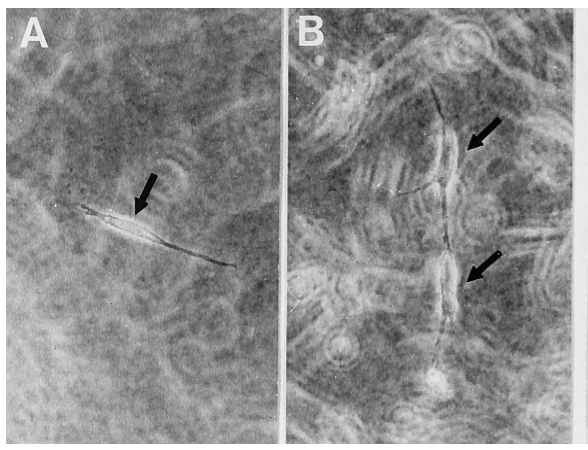

Fig. 3. Endothelial cell morphology invading underlying control $(\mathbf{A}, \mathbf{B})$ and glycated collagen gels $(\mathbf{C}, \mathbf{D})$. Photographs were taken under phase-contrast microscopy at day $2.300 \times$. Arrows indicate spindle shaped endothelial cells (A, B). Arrow heads indicate the cells with ruffles $(\mathbf{C})$ and with cytoplasmic extensions (D)

Fig. 4. Endothelial cell morphology on or within collagen gels. Endothelial cells were cultured with angiogenic factors for 7 days on control collagen (B) or collagen gels pretreated with glycolaldehyde in the absence $(\mathbf{C}, \mathbf{D})$ or presence of aminoguanidine $(\mathbf{E})$, or $\mathrm{NaCNBH}_{3}(\mathbf{F})$. Capillary-like cords were observed within gels (B, E, F). Immature cords (arrows, C) and elongated endothelial cells (arrows, D) were seen in the glycated collagen gel. A, Endothelial cells grown on collagen gel without angiogenic factors. (A-C, E, F: $200 \times$; D: $300 \times$ )

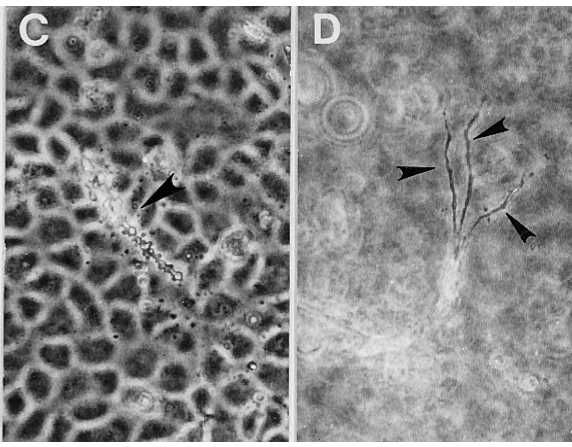

Effect of glycation on endothelial cell proliferation on collagen fibrils. We examined whether glycation of collagen may affect endothelial cell proliferation. As shown in Figure 5A, no effect of glycation on endothelial cell proliferation was observed on collagencoated wells in the presence or absence of angiogenic factors. In contrast, on glycated collagen gel, endothelial cell proliferation was significantly stimulated compared with that on control collagen gel (Fig. 5B). This effect was also observed in the presence of angiogenic factors (Fig.5B). When endothelial cells were proliferated on collagen gels pretreated in glycolaldehyde in the presence of aminoguanidine or $\mathrm{NaCNBH}_{3}$, increased cell proliferation was not observed on collagen gels with or without angiogenic factors (Fig. 5B). It should be noted that endothelial
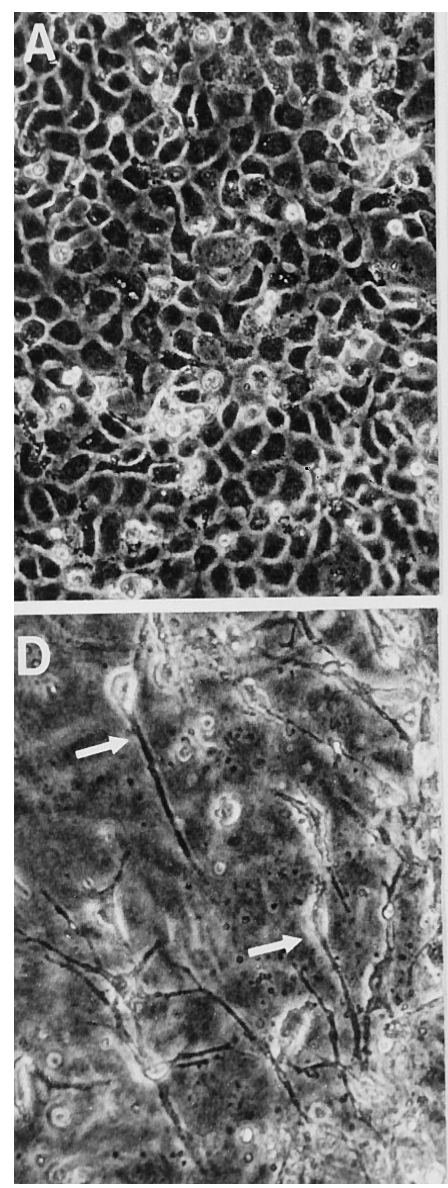
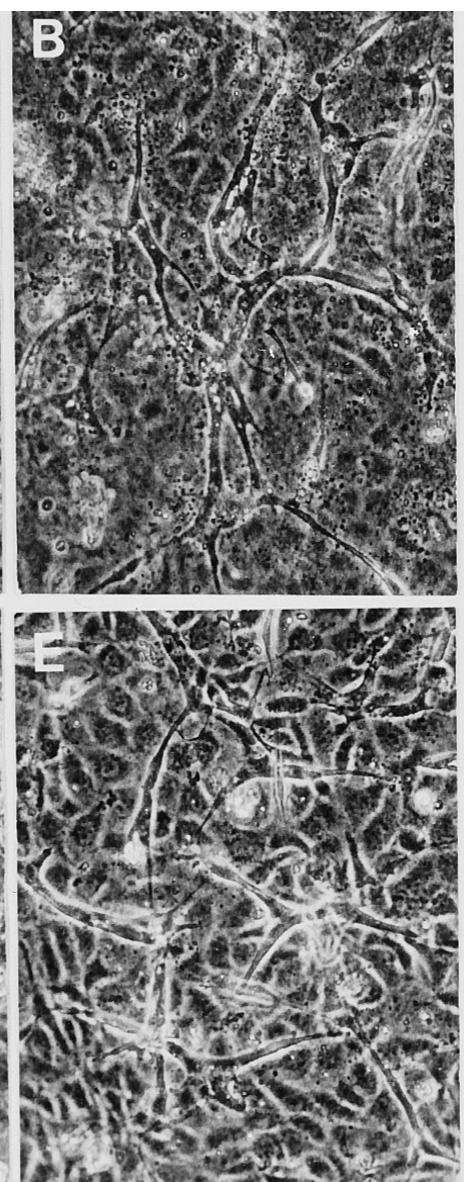
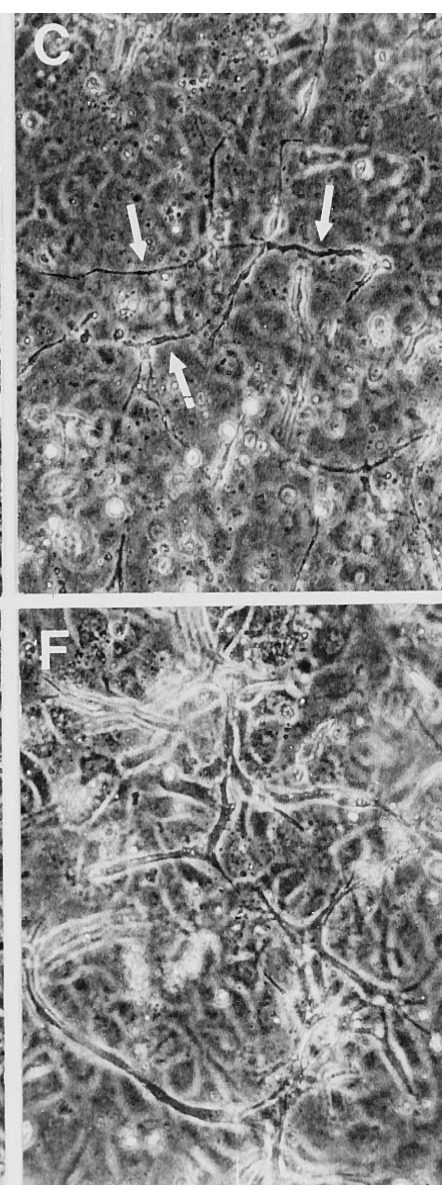
Table 1. The effect of glycation on endothelial cell invasion into collagen gel

\begin{tabular}{|c|c|c|c|c|}
\hline \multirow{3}{*}{$\begin{array}{l}\text { Angiogenic } \\
\text { factors }\end{array}$} & \multicolumn{4}{|c|}{ Invading cell number/field } \\
\hline & \multicolumn{4}{|c|}{ Collagen gel treatment } \\
\hline & Control & $\begin{array}{l}\text { Glycolalde- } \\
\text { hyde(GA) }\end{array}$ & $\begin{array}{l}\text { GA + amino- } \\
\text { guanidine }\end{array}$ & $\begin{array}{l}\mathrm{GA}+ \\
\mathrm{NaCNBH}_{3}\end{array}$ \\
\hline$\overline{(-)}$ & $2.0 \pm 0.6$ & $1.1 \pm 0.4$ & $2.3 \pm 0.4$ & $2.7 \pm 0.7$ \\
\hline$(+)$ & $39.6 \pm 4.8$ & $7.1 \pm 1.8^{\mathrm{a}}$ & $33.6 \pm 3.3$ & $35.8 \pm 4.6$ \\
\hline
\end{tabular}

Collagen gels were treated with glycolaldehyde in the presence or absence of aminoguanidine, or $\mathrm{NaCNBH}_{3}$. Endothelial cells were seeded on these gels and incubated in the presence of angiogenic factors (FGF-2 plus VEGF) for 2 days. Invading cells were counted under phase contrast microscopy at a magnification of $\times 200$. Values represent the means \pm SEM of the cell number from four randomly selected fields of duplicated wells. ${ }^{\mathrm{a}} p<0.0001$ compared with control with angiogenic factors

Table 2. The effect of glycation on endothelial cell migration

\begin{tabular}{lcc}
\hline Angiogenic factors & Cell number/field & \\
\cline { 2 - 3 } & Control & $\begin{array}{l}\text { Glycolaldehyde } \\
\text { treatment }\end{array}$ \\
\hline$(-)$ & $0.9 \pm 0.3$ & $1.1 \pm 0.4$ \\
$(+)$ & $256.5 \pm 12.6$ & $255.9 \pm 14.2$ \\
\hline
\end{tabular}

Migration was measured in endothelial cells as chemotaxis toward angiogenic factors (FGF-2 plus VEGF). Transwell membranes were coated with collagen type I, and then treated with phosphate buffer (control) or glycolaldehyde in phosphate buffer. Values represent the means \pm SEM of the cell number from eight randomly selected fields $(\times 400)$ of duplicated chambers

cells proliferated more rapidly on collagen-coated well than on collagen gel.

Effect of glycation on proteinase production from endothelial cells. Exposure of endothelial cells on control collagen gel to angiogenic factors for $24 \mathrm{~h}$ increased the endothelial cell-associated plasminogen activator activity and no difference in the level was observed between control and glycated collagen gel (Fig.6A). MMPs activity in conditioned medium from endothelial cells cultured on collagen gel for $32 \mathrm{~h}$ was increased in the presence of angiogenic factors (Fig. 6B). Again no difference in MMPs activity in conditioned medium was observed between control and glycated collagen gel in the absence or presence of angiogenic factors. Although endothelial cell-associated MMPs activity was also determined, the activity was much less than that in the conditioned medium and no significant difference was detected between the control and glycated collagen gel.

\section{Discussion}

In the present study we showed that endothelial cell invasion and subsequent angiogenesis processes in the presence of angiogenic factors were inhibited on a glycated three-dimensional collagen lattice.

The formation of new blood vessels is believed to occur when sub-populations of endothelial cells are activated to migrate away from their parent vessels to form new vessels at distant sites. Proteinase secreted from endothelial cells plays an important role in endothelial cell migration through the basement membrane and the interstitial matrix. In fact, the importance of matrix proteinase activity in angiogenic response is supported by several lines of evidence $[17,27,28]$. It is assumed that endothelial cell plasminogen activator-plasmin system and members of the MMP superfamily are involved in the regulation of local proteolytic remodelling of matrix proteins during angiogenesis processes $[17,27]$. Plasmin generated from its inactive precursor plasminogen by plasminogen activators degrades certain matrix components such as laminin and proteoglycans and also activates MMP zymogens [29].

It is conceivable that the decrease in endothelial cell invasion and the inhibition of subsequent angiogenesis might be due to the reduction of plasminogen activator or MMPs production from endothelial cells cultured on glycated collagen gel. However, this is unlikely in our situation, since we showed no difference either in endothelial cell-associated plasminogen activator activity or MMP levels, in the conditioned medium between control and glycated collagen gels.

We previously showed that glycation of laminin impaired the normal interaction of the endothelial cell receptor with its specific laminin ligand [8]. In addition, AGE molecules in glycated laminin act as ligands for endothelial cell receptors. These changes in the interaction between the endothelial cell receptor and its specific laminin ligand result in the inhibition of endothelial cell differentiation on glycated, reconstituted basement membrane protein complex. In the case of collagen, it is unlikely that AGE molecules are responsible for the cell collagen molecule interaction, since soluble AGEs did not inhibit endothelial cell attachment on glycated collagen gel and did not modulate the angiogenesis process. In addition, glycated collagen molecules did not affect angiogenic factor-directed endothelial cell migration.

Consistent with previous observations $[4,5]$, we showed that AGE formation is associated with the structural alteration of matrix components, such as collagen-to-collagen cross-linking, which leads to a decrease in solubility and susceptibility to proteolytic enzymes. The present study cannot define the exact mechanism of these modifications of endothelial cell behaviour on or within cross-linked collagen gel. However, we suggest that this cross-linking may be 
A

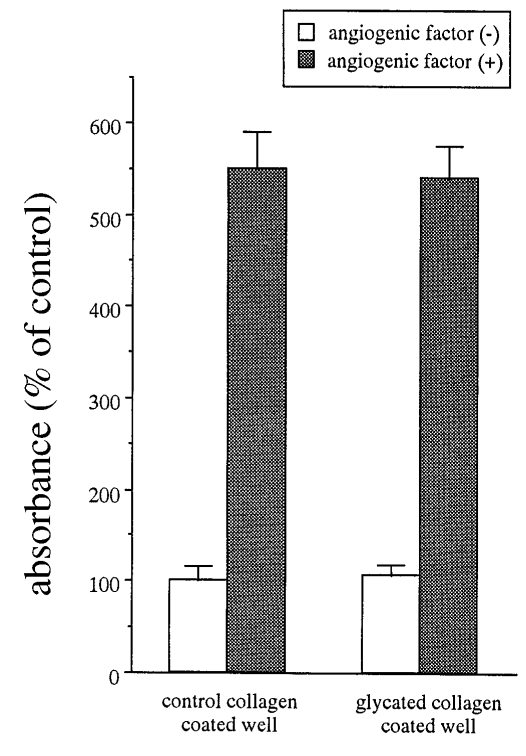

B

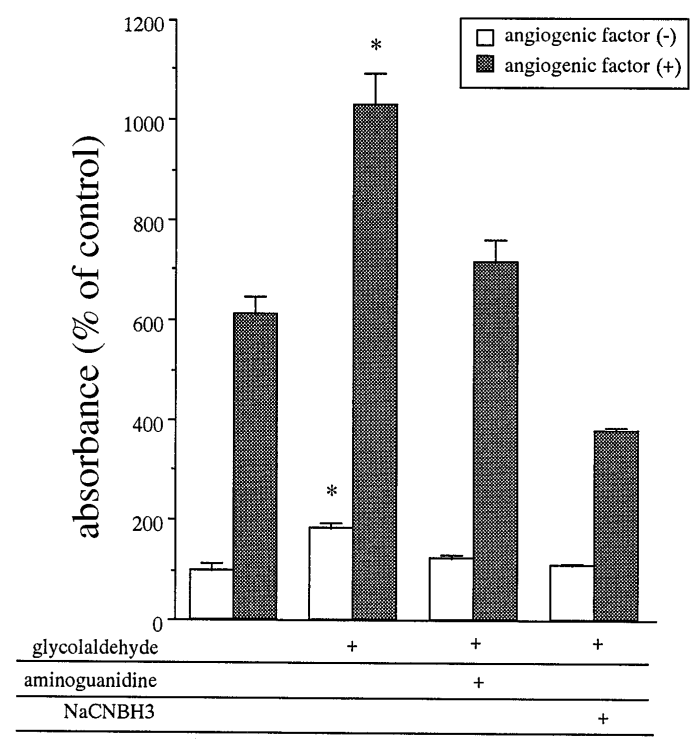

Fig. 5. Effect of glycation on endothelial cell proliferation on collagen-coated wells and collagen gel. Endothelial cells were seeded on collagen-coated wells which were pretreated with or without glycolaldehyde (A), or on collagen gels which were pretreated with glycolaldehyde in the presence or absence of aminoguanidine or $\mathrm{NaCNBH}_{3}(\mathbf{B})$. Following 3 days incubation at $37^{\circ} \mathrm{C}$ with or without angiogenic factors (FGF$2+\mathrm{VEGF}$ ), the cell number was determined colourimetrically as described in Material and methods. Data are expressed as means $\pm \operatorname{SEM}(n=4)$ and a percentage of sample absorbance to control without angiogenic factors. ${ }^{*} p<0.01$ vs control

involved in the inhibition of endothelial cell invasion and in morphological changes in glycated collagen fibrils. Further that this is mediated by the inhibition of the fibrillar collagen remodelling through the reduction of the susceptibility of collagen molecules to proteolytic degradation.

Although matrix proteins alter cell behaviour through specific binding interaction with cell surface receptors [6,7], the biological effects of matrix components also vary greatly depending upon their structural configuration $[11,12]$. In fact, a variety of cells proliferate on rigid, collagen-coated dishes, but differentiate when cultured on or within malleable collagen fibrils $[30,31]$. It has been proposed that mechanical interactions between endothelial cells and extracellular matrix modulate endothelial proliferation and differentiation (angiogenesis) [11, 12]. Thus, it is also possible that altering the mechanical integrity of fibrillar collagen by glycation-induced cross-link formation may contribute to the inhibition of angiogenesis process on glycated collagen gel.

This possibility is supported by our observation that endothelial cell proliferation was stimulated on glycated collagen gel compared with that on control gel in the presence or absence of angiogenic factors. It should be noted that this effect of glycation is not endothelial cell specific, since cultured vascular smooth muscle cell proliferation was also enhanced on glycated collagen gel (S. Kanda; unpublished observation). AGEs formation is essential for the effect on cell proliferation, since inclusion of aminoguanidine and $\mathrm{NaCNBH}_{3}$ during the glycation reaction completely recovered this effect of glycation. The stimulatory effect of glycated collagen gel on cell proliferation is not mediated by the AGE molecule itself, since no effect on endothelial cell proliferation was observed on thin coated-glycated collagen on the rigid culture dish. As described in the results, endothelial cells proliferate more rapidly on rigid, collagencoated wells than on collagen gel, consistent with the recent report by Koyama et al.[30], suggesting the biological effect of matrix proteins is dependent on their physical characteristics. AGE-induced crosslinking in collagen fibrils, which leads to physical changes such as stiffness of the fibrils, may be involved in the enhanced cell proliferation on glycated collagen gel. However, further studies are required to evaluate the exact mechanism of the stimulatory effect of glycated collagen gel on endothelial cells.

In the present study we have demonstrated that glycation of fibrillar collagen introduces the crosslink formation. These structural alterations of fibrillar collagen modulate endothelial cell invasion, capillary-like cord formation, and proliferation in or on collagen fibrils. It has been shown that in diabetes there is an inadequate ischaemia-induced angiogenesis and impairment of wound healing has been observed with a decreased neovascularization in diabetic patients and animals $[32,33]$. Matrix protein cross- 
A

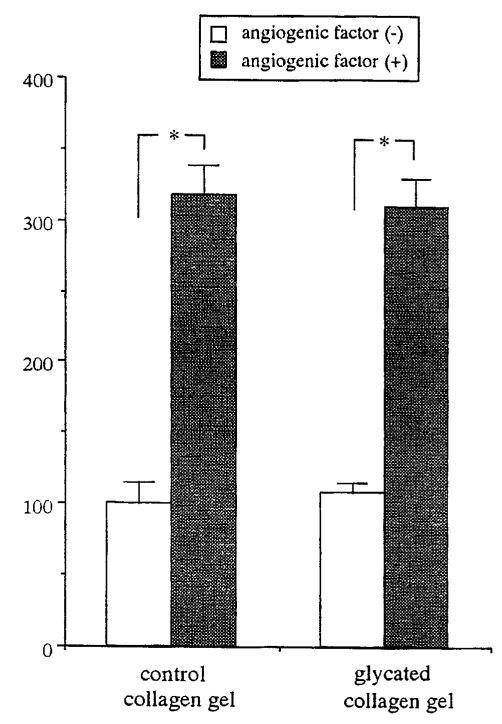

Fig. 6. Effect of glycation on endothelial cell-associated plasminogen activator activity (A) and matrix metalloproteinase activity in conditioned medium (B). A, Endothelial cells cultured on control or glycated collagen gels were incubated with or without angiogenic factors (FGF-2 + VEGF) at $37^{\circ} \mathrm{C}$. Following $24 \mathrm{~h}$ incubation, cell-associated plasminogen activator activity was determined colourimetrically as described in Materials and methods. B, Endothelial cells cultured as described above except for the condition without serum. Following $32 \mathrm{~h}$ incubation, conditioned medium was collected, and activated with p-aminophenylmercuric acetate. Matrix metalloproteinase activity was then determined fluorometrically as described in Materials and methods. Data are expressed as means \pm SEM $(n=4)$ and a percentage of sample absorbance to control without angiogenic factors. $* p<0.001, * * p<0.01$

linking may at least in part contribute to this diminished capacity to vascularize in diabetes through altering the structural configuration of matrix proteins as well as impairing normal interactions with endothelial cell receptors.

Acknowledgements. We thank Miss Michiko Doi and Mrs. Norie Kametsuta for expert technical assistance. The research was supported by grants from Research Projects on Health and Aging, and from Aichi D.R.G. Foundation.

\section{References}

1. Monnier VM, Vishwanath V, Frank KE, Elmets CA, Dauchot P, Kohn RR (1984) Relation between complications of type I diabetes mellitus and collagen-linked fluorescence. N Engl J Med 314: 403-408

2. Brownlee M, Cerami A, Vlassara H (1988) Advanced glycosylation end products in tissue and the biochemical basis of diabetic complications. N Engl J Med 318: 1315-1321

3. Monnier VM, Kohn RR, Cerami A (1984) Accelerated age-related browning of human collagen in diabetes mellitus. Proc Natl Acad Sci USA 81: 583-587
B

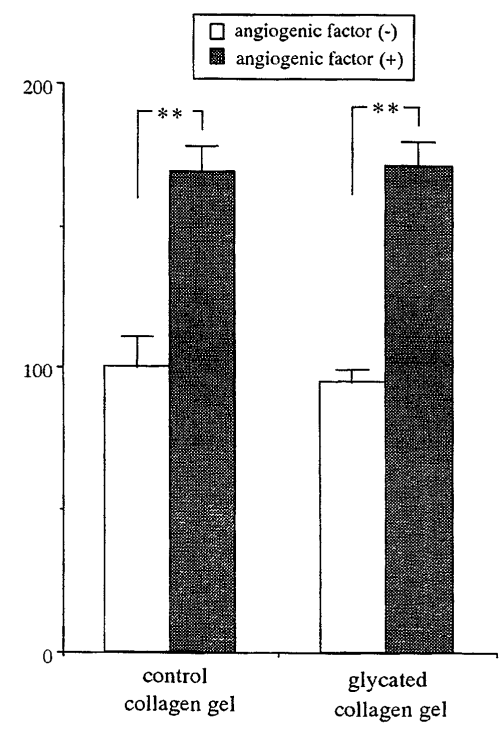

4. Vlassara H, Bucala R, Striker L (1994) Pathogenic effects of advanced glycosylation: biochemical, biologic, and clinical implications for diabetes and aging. Lab Invest 70: 138-151

5. Brownlee M (1994) Glycation and diabetic complications. Diabetes 43: 836-841

6. Hynes RO (1992) Integrin: versatility, modulation, and signaling in cell adhesion. Cell 69: 11-25

7. Clark EA, Brugge JS (1995) Integrins and signal transduction pathways: the road taken. Science 268: 233-239

8. Kuzuya M, Satake S, Miura H, Hayashi T, Iguchi A (1996) Inhibition of endothelial cell differentiation on a glycosylated reconstituted basement membrane complex. Exp Cell Res 226: 336-345

9. Yue DK, McLennan S, Delbridge L, Handelsman DJ, Reeve T, Turtle JR (1983) The thermal stability of collagen in diabetic rats: correlation with severity of diabetes and non-enzymatic glycosylation. Diabetologia 24: 282-285

10. Kent MJC, Light ND, Bailey AJ (1985) Evidence for glucose-mediated covalent cross-linking of collagen after glycosylation in vitro. Biochem J 225: 745-752

11. Ingber DE, Folkman J (1989) Mechanochemical switching between growth and differentiation during fibroblast growth factor-stimulated angiogenesis in vitro: role of extracellular matrix. J Cell Biol 109: 317-330

12. Vernon RB, Sage EH (1995) Between molecules and morphology. Extracellular matrix and creation of vascular form. Am J Pathol 147: 873-883

13. Folkman J, Shing Y (1992) Angiogenesis. J Biol Chem 267: 10931-10934

14. Klagsbrun MK, D'Amore PA (1991) Regulation of angiogenesis. Annu Rev Physiol 53: 217-239

15. Nicosia RF, Madri JA (1987) The microvascular extracellular matrix: developmental changes in the aortic ring-plasma clot model. Am J Pathol 128: 78-90

16. Madri JA, Marx M (1992) Matrix composition, organization and soluble factors: modulators of microvascular cell differentiation in vitro. Kidney Int 41: 560-565

17. Montesano R, Orci L (1985) Tumor-promoting phorbol esters induce angiogenesis in vitro. Cell 42: 469-477

18. Motesano R, Orci L, Vassalli P (1983) In vitro rapid organization of endothelial cells into capillary-like networks in promoted by collagen matrices. J Cell Biol 97: 1648-1652 
19. Grant DS, Tashiro KI, Segui-Real B, Yamamoto Y, Martin GR, Kleinman HK (1989) Two different laminin domains mediate the differentiation of human endothelial cells into capillary-like structures in vitro. Cell 58: 933-943

20. Kuzuya M, Satake S, Esaki T et al. (1995) Induction of angiogenesis by smooth muscle cell-derived factor: possible role in neovascularization in atherosclerotic plaque. J Cell Physiol 164: 658-667

21. Acharya AS, Manning JM (1983) Reaction of glycolaldehyde with proteins: Latent crosslinking potential of a-hydroxyaldehydes. Proc Natl Acad Sci USA 80: 3590-3594

22. Brownlee M, Vlassara H, Kooney A, Ulrich P, Cerami A (1986) Aminoguanidine prevents diabetes-induced arterial wall protein cross-linking. Science 232: 1629-1632

23. Thomas KA (1996) Vascular endothelial growth factor, a potent and selective angiogenic agent. J Biol Chem 271: 603-606

24. Pepper MS, Ferrara N, Orci L, Montesano R (1992) Potent synergism between vascular endothelial growth factor and basic fibroblast growth factor in the induction of angiogenesis in vitro. Biochem Biophys Res Commun 189: 824-831

25. Goto F, Goto K, Weundel K, Folkman J (1993) Synergistic effects of vascular endothelial growth factor and basic fibroblast growth factor on the proliferation and cord formation of bovine capillary endothelial cells within collagen gels. Lab Invest 69: 508-517
26. Knight CG, Willenbrock F, Murphy G (1992) A novel coumarin-labelled peptide for sensitive continuous assays of the matrix metalloproteinases. FEBS Lett 296: 263-266

27. Sato Y, Okamura K, Morimoto A et al. (1993) Indispensable role of tissue-type plasminogen activator in growth factor-dependent tube formation of human microvascular endothelial cells in vivo. Exp Cell Res 204: 223-229

28. Fisher C, Gilbertson-Beadling S, Powers EA, Petzold G, Poorman R, Mitchell MA (1994) Interstitial collagenase is required for angiogenesis in vitro. Dev Biol 162: 499-510

29. Vassali JD, Sappino AP, Belin D (1991) The plasminogen activator/plasmin system. J Clin Invest 88: 1067-1072

30. Koyama H, Raines EW, Bornfeldt KE, Roberts JM, Ross R (1996) Fibrillar collagen inhibits arterial smooth muscle proliferation through regulation of Cdk2 inhibitors. Cell 87: 1067-1078

31. Sankar S, Mahooti-Brooks N, Bensen L, McCarthy TL, Centrella M, Madri JA (1996) Modulation of transforming growth factor $\mathrm{b}$ receptor levels on microvascular endothelial cells during in vitro angiogenesis. J Clin Invest 97: 1436-1446

32. Yarom R, Zirkin H, Stammler G, Rose G (1992) Human coronary microvessels in diabetes and ischemia. Morphometric study of autopsy material. J Pathol 166: 265-270

33. Fahey III TJ, Sadaty A, Jones II WG, Barber A, Smoller B, Shires GT (1991) Diabetes impairs the late inflammatory response to wound healing. J Surg Res 50: 308-313 